\title{
Estudos argentinos
}

CISNEROS, Andrés \& IÑIGUEZ, Carlos Piñeiro. Del ABC al Mercosur: la integración latinoamericana em la doctrina y práxis del peronismo. Buenos Aires: ISEN/Nuevo Hacer/Grupo Editor Latinoamericano, 2002, 601 p. ISBN: 9506946817.

NOVARO, Marcos \& PALERMO, Vicente. La dictadura argentina (19761983): del golpe de estado a la restauración democrática. Buenos Aires: Paidós, 2003, 576 p. ISBN: 9501277097.

RAPOPORT, Mario. Tiempos de crisis, vientos de cambio: Argentina y el poder global. Buenos Aires: Grupo Editorial Norma, 2002, 403 p. ISBN: 9875450812.

SEBRELLI, Juan José. Crítica de las ideas políticas argentinas. $6^{a}$ edición. Buenos Aires: Sudamérica, 2003, 512 p. ISBN: 9500722739.

O triênio 2000-2003 foi de intensidade singular para a vida social, econômica e política da República Argentina, cenário que tem sido alvo de estudos por parte de internacionalistas e pesquisadores de áreas conexas. No caso dos historiadores, a prudência os leva a aguardar mais alguns anos para se aventurarem a explicar os acontecimentos passados no período. De qualquer forma, a explicação dos fenômenos da atualidade não é feita apenas no presente mas principalmente pelo retorno ao passado, pela apreciação de recorrências factuais e pela utilização de regularidades e analogias.

Nessa linha, a obra de Raul Bernal-Meza, Sistema Mundial y Mercosul (Buenos Aires: Grupo Editor Latinoamericano, 2000), seria um marco dos estudos argentinos sobre a nova configuração da política internacional, tendo como pano de fundo a inserção da Argentina nesse mundo, característica marcante dos estudiosos portenhos de relações internacionais. Destarte, a dinâmica da produção argentina, tradicionalmente intensa, permaneceria fornecendo trabalhos consistentes sobre a atualidade, valendo-se da perspectiva histórica como instrumento-chave de análise.

Assim, um quadro explicativo sobre a atual situação argentina, e suas repercussões para a América do Sul, pode ser desenhado da convergência de elementos extraídos dessas quatro obras. Primeiro, é fundamental entender o papel das idéias como fator cultural de poder capaz de influenciar os rumos da política exterior de um país, principalmente ao fornecer parâmetros de ação e mapas para as tomadas de decisão. Nesse sentido, a discussão apresentada por Juan José Sebrelli em sua obra Crítica de las ideas políticas argentinas, escrito em 2001 e entrando na sua $6^{\text {a }}$ edição no ano de 2003, mostra-se relevante uma vez que "no solo la fuerza de las cosas, tambíen el sistema de valores, los estilos de pensamiento, 
las ideas, los ideales, las ideologias, las creencias, los mitos [...] juegan en política un papel decisivo". Assim, o objetivo da obra é o de entender as origens das crises vividas pelo país, a partir de modificações na estrutura de poder interno, que viu seu domínio ser retirado das mãos dos partidos políticos e passado a grupos de interesse.

O autor toma como ponto focal as idéias que guiaram as correntes políticas argentinas ao longo de sua história, iniciando sua análise evolutiva na década de 1980 do século XIX, com Domingos Sarmiento e sua influência sobre os políticos argentinos da República Conservadora. Avança para a transição do liberalismo ao nacionalismo, com a invenção da nacionalidade argentina constituída com a organização definitiva do Estado em 1880 e a elevação de Buenos Aires a capital da República. Paralelamente ao ocaso do nacionalismo e ao nascimento do pensamento de esquerda nas décadas de 1950 e 1960 do século XX, surgiria no horizonte político argentino uma das correntes mais importantes de pensamento da América do Sul, qual seja o Peronismo. O autor aponta, então, suas aproximações com a igreja e com o exército, procura decifrar o mito do antiimperialismo e apresenta o totalitarismo como característica marcante dessa corrente de pensamento, que o coloca entre o bonapartismo e o fascismo.

Contudo, os imbricamentos surgidos dentro da própria corrente peronista, com variâncias entre o radicalismo, o nacionalismo e a vertente de esquerda, levou o país a um estancamento intelectual e à conformação de um vácuo ideológico, só posteriormente preenchido pelo militarismo, base de pensamento dos regimes de força que se institucionalizariam em 1976 com o Governo de Rafael Videla.

É desse controverso episódio da vida política argentina que trata o livro de Marcos Novaro e Vicente Palermo, La dictadura argentina (1976-1983): del golpe de estado a la restauración democrática. Trata-se de uma obra que compõe a coleção História Argentina - que aspira cobrir o curso completo da história nacional daquele país - e que tem como objetivo principal traçar a trajetória do chamado Proceso de Reorganización Nacional. Para tanto, os autores seguem desde os antecedentes do golpe de 24 de março de 1976, passando pelo diagnóstico e os planos da cruzada restauradora que levariam ao nascimento del imperio de la muerte, com o colapso das guerrilhas e a constituição de uma nova ordem baseada na dicotomia segurança/temor. Os anos seguintes seriam de adaptação às mudanças internas e externas, sendo Videla forçado a rever seu plano político e econômico, o que imporia ao país a primeira fuga hacia adelante, no final de 1978. Sua saída foi postergada por oito meses, uma longa transição até que Viola assumisse o poder em 24 de março de 1981.

Por fim, os autores apresentam os derradeiros anos do regime militar, com o governo de Galtieri, o episódio da Guerra das Malvinas e a transição para a ordem democrática. Nesse sentido, a campanha eleitoral e a vitória de Raúl 
Alfonsín se tornaram um momento definidor da história argentina, abrindo uma janela de oportunidade para o país dentro da América do Sul, com a possibilidade de reaproximação com o Brasil por meio da conformação do Mercosul.

Partia-se, então, para uma nova era de concertação e aproximações dentro do espaço sul-americano, mas que necessariamente deveria ser visto da confluência entre o presente e o passado. É esse o objetivo da obra de Andrés Cisneros e Carlos Piñeiro Iñiguez, Del ABC al Mercosur: la integracion latinoamericana em la doctrina y práxis del peronismo, que se propõe a fazer uma ponte entre o que é hoje o projeto Mercosul, sua importância política e econômica, e o que foi o Pacto ABC, revisitado por Perón em meados da década de 1960 do século XX. De fato, a linha mestra da obra se basea na noção de que alguns estadistas têm a capacidade de modificar a realidade pré-existente a partir de um curso próprio de idéias e ações, ou seja, atuando como pensadores e executores. Nesse sentido, eles se referem ao Barão do Rio Branco e ao Presidente argentino Juan Domingo Perón como profetas que anteciparam a união dos povos sul-americanos, não como uma verdade revelada, mas como uma visão de políticos que conseguiram transcender sua circunstância e conjuntura, se convertiendo en contemporáneo[s] de la posteridad.

O livro procura mostrar ainda o processo de construção de uma nação de nações sul-americanas, apontando a linha de continuidade existente entre diversas políticas de unidade latino-americanas, desde o novo Pacto ABC, de Perón, até a conformação do Mercosul, momento em que a idéia de integração se torna realidade, mas sempre tendo como baliza a influência que exerce a intuição política na formulação e condução dos processos sociais.

De fato, valoriza-se a capacidade do peronismo de funcionar como ponto focal da política exterior argentina a partir da década de 1950. Para tanto, os autores fazem uma retrospectiva da formação do pensamento peronista; suas aproximações com Vargas no Brasil, Haya de la Torre no Peru, Cardenas no México, acentuando a importância de se pensar desde la periferia, sua consolidação como corrente teórica e sua aplicação prática em dois momentos específicos da história da política exterior argentina: os alcances e consequências da opção peronista pela terceira posição e a proposta peronista de um novo ABC. Paralelamente, se discute a política exterior dos países do Cone Sul, fundamentalmente de Brasil e Chile, componentes do pacto idealizado pelo Barão. Além disso, os autores avançam sobre trinta anos decisivos para a história latino-americana, de formação das associações de livre comércio, dos regimes militares até o amadurecimento do pensamento integracionista, com o que chamam de a forma mais avançada da integração latino-americana, o Mercosul. Concluem, então, retomando a importância dos profetas, como Perón e Rio Branco, para a conformação de uma história ainda inconclusa e que sofre revezes constantes, como as crises que afetaram Brasil e Argentina no final do século XX e início do XXI. 
O livro de Mario Rapoport, Tiempos de crisis, vientos de cambio: Argentina y el poder global, fecha o círculo explicativo com uma apreciação sintomática dos problemas argentinos atuais. Um estudioso que se move bem entre a história das relações internacionais e a politologia e que consegue fazer de uma obra composta por uma série de artigos e entrevistas, sobre temas específicos, um trabalho uníssono, organizado e dividido em três partes. Na primeira parte, fala da globalização e da crise mundial, preocupando-se em traçar um quadro amplo dos mitos em torno dos elementos que definem esse processo, bem como em colocar na berlinda o chamado pensamento único liberalizante que dominaria a América do Sul no pós-Guerra Fria. Na segunda, ajusta seu foco de análise para entender a crise argentina mais de perto, ao buscar as raízes de seu malogro no passado, desde o processo de endividamento externo e do fantasma da hiperinflação, passando pela ilusão dos contatos e da imitação do gran hermano, até o impacto das guerras mundiais para a Argentina. Além disso, apresenta um recorte de alguns momentos importantes da política externa argentina: relações com os Estados Unidos, os governos militares e o dilema argentino entre o Mercosul e a Alca. Na terceira parte, composta eminentemente por entrevistas do autor, é discutida a contemporaneidade dos problemas argentinos, a partir de pequenas peças que, juntas, decifram um dos quebra-cabeças da crise não só argentina, mas de toda a América do Sul. 